\title{
The Criminalization of Functional Officer In Charge Of Document Examination In Criminal Corruption Courts
}

\author{
Yuliana Setiadi \\ \{martineyuliana@gmail.com\} \\ Doctor of Law, Universitas Jayabaya, Jakarta, Indonesia
}

\begin{abstract}
Various phenomenon regarding criminal law system, especially in relation to law enforcement against corruption have led to lower public trust in law enforcement officers, particularly in providing legal certainty and justice against corruption cases that are very detrimental to the state. This normative juridical legal research was carried out to obtain data relevant to this problem. This research regarded primary, secondary and tertiary legal materials which were then analyzed using descriptive analysis. Two theories underlie this research including the theory of legal certainty and the theory of authority. The results showed that discretion done by State Administrative Officials is a State Administrative Law Act, if it is performed by a State Administrative Official in a certain case where none of the existing laws and regulations regulate the issue, or if the existing regulations are unclear that freedom of judgment from the State Administrative Official is required. In addition, the action can only be carried out in a compelling / urgent situation for the sake of the public interest as stipulated in a statutory regulation. Legal certainty and justice must be guaranteed for the state administration in carrying out this duty by designing legal instrument that regulates all processes of government administration. In order to run a dynamic governance, laws and regulations that regulate the government administration system including the decision-making process (Material State Administrative Law) need to be developed.
\end{abstract}

Keywords: Discretion; Corruption; Criminal Law; Legal Certainty

\section{Introduction}

Talking about the public interest is closely related to the authority possessed by the government in the context of administering government. From a legal perspective, the service of the public interest is also a form of obligation that has been mandated by the Constitution to the government to provide public welfare. To carry out national development requires broad, real and responsible authority to serve the interests of the community based on the principles of expediency, fairness, openness, and participation and accountability to the community. Since the state has actively participated in community relations, government jobs have been getting wider and wider. State administration is entrusted with the obligation to organize public welfare (bestuurzorg) (Syahnaz, 2021).

The expansion of aspects of social life and public welfare in general indirectly has an impact on the expansion of the role of state administration officials in providing services to the public. Because of the wide scope of government administration tasks, regulations are needed that can 
regulate the administration of government in accordance with the needs of the community. As the growth and development of the role of officials of state administration must deal with the fact widespread aspects of social life and the welfare of society at large, so ideally any problems and actions to be taken by an official of the state administration in the functioning of public services has been provided the rules (Taufiqqurahman, 2019).

Changes in dynamics that occur so quickly in aspects of social life and the welfare of society in general, indirectly make a state administration official have to change his thinking paradigm. The obedience of a state administration official to the rules made by the government or his superiors is a form of true obedience, but it should also be understood that the rules made are also man-made. As an ordinary human being who has bounded rationality, the rules made of course are not able to regulate all interests that occur in society. No matter how quickly a rule is made, it will not be able to answer the dynamic changes that occur in society, because the dynamic changes that occur in society are so fast, and not all changes that occur are regulated in a rule.

In the face of such conditions, it is impossible for a state administration official to be unable to do something by reason of waiting until a rule is made or waiting for a new rule (rechtsvacuum) (Pratama, 2019). If this is done by a state administration official, then it is tantamount to inhibiting changes in the dynamics of the community so that it can result in the community itself making the rules. Therefore, in such conditions the bureaucracy is expected to be able to have dual or multiple functions in the sense of a government apparatus not only as an executor or policy implementer but also as a formulator and policy evaluator at the same time. In order to be able to carry out the task of organizing people's welfare, conducting teaching for all citizens and so on properly, the state administration needs independence to be able to act on its own initiative, especially in solving urgent problems that arise suddenly and the implementation regulations do not yet exist, namely: has not been made by state agencies entrusted with legislative functions.

The granting of authority to state administration officials to act on their own initiative is known as freies ermesen/discreationary power or in Indonesian known as discretion (Jemi, Sudibyo, \& Wahyuengeseh, 2019) which is a term that contains broad obligations and powers. Obligations are actions that must be carried out while broad power implies freedom of choice; take or not take action. Discretion can be said to be a freedom given to state administration tools, namely freedom which in principle allows state administration tools to prioritize the effectiveness of achieving a goal rather than adhering to legal provisions, or legal authority to interfere in social activities in order to carry out tasks. serve the public interest. Therefore, a state administration official in carrying out the tasks of administering the public interest must not only depend on or based on the presence or absence of a rule.

In the practice of state administration, it is not uncommon for state administrative legal actions or actions to be carried out by government officials intended to provide protection to the community or to overcome compelling urgencies, causing violations or irregularities and/or causing losses to state finances which by the judge, prosecutors, police, and the KPK are qualified as criminal acts of corruption, resulting in the imposition of criminal sanctions and administrative sanctions in the form of dismissal or dismissal of government officials from their positions as civil servants. This has very serious implications, because it creates a phenomenon of fear, reluctance, and doubt of state officials to take administrative legal actions or actions, thus affecting the performance of government officials and disrupting the administration of government as a whole.

Administrative law is dominated by the term discretion. The term often defines the function of an organ and describes the role of the courts in conducting tests. Therefore, it is very 
important for the court to understand the administrative discretion both to evaluate the performance of an organ and to understand the function of the court itself. The term discretion has at least five meanings in administrative law (Koch, 1985):

a. The authority to make individual decisions in the application of general rules is referred to as "individualizing discretion";

b. The freedom to fill vacancies within the delegated authority for the purpose of performing designated administrative functions is referred to as "executing discretion";

c. The power to take action in the context of a common goal is referred to as "policymaking discretion";

d. If testing is not permitted, the organ that makes the decision is considered to be exercising "unbridled discretion";

e. Meanwhile, if testing is not permitted in principle, the decision-making organ is considered to be exercising "numinous discretion".

The different functions of the court relate to the distinction of the above types of discretion. Although one of the objectives of the state is a state of law, but the direction or the main goal is the welfare state (Sitorus, 2016). Therefore, executive officials who are more in contact with the implementation of the law cannot be limited to inaction, when there is a legal vacuum (wetvacuum) and there are regulations implementing the law that need to be interpreted (interpertate) (Sitorus, 2016). However, it should still be noted that even though it is an official discretionary act, it must be legally and morally accountable (Koch, 1985).

Discussing state policies (staatsbeleid), abuse of authority (de tournement de pouvoir) which is a discussion of State Administrative Law, then used by Criminal Law, for example contained in the element of "abusing authority" (Article 1 paragraph (1) b of Law Number 3 Year 1971 in conjunction with Article 3 of Law Number 31 of 1999), the element of "against the law" (Article 1 paragraph (1) letter a of Law Number 3 of 1971 in conjunction with Article 2 paragraph (1) of Law Number 31 of 1999), the element "may harm the state's finances or the state's economy" Article 2 paragraph (1) of Law Number 31 of 1999 jo. Law No. 20 of 2001. If you look at the characteristics and modus operandi of a criminal act of corruption, it can be explained that the tendency of a public official to be exposed to a corruption case may occur because of a criminal act of corruption, one of the characteristics is subterfuge, concealment of reality, misleading and on the dimension of crime that always uses power and in the 11 (eleven) scope of office and work (Setiadi, 2010).

\section{Research Methods}

The research method used by researchers in this journal is a normative juridical approach using justice theory and library methods. The research stages use primary legal materials, secondary legal materials, and tertiary legal materials to complete secondary data obtained through the literature.

\section{Results and Discussion}

\section{The Legitimacy of the Authority of State Administration Officials}

In other words, every organization of state and government have legitimacy, the authority granted by legislation - legislation to take action - certain legal actions (Atmosudirdjo, 1981). 
To assess the authority of an official in making a policy, the source of the authority of the official who makes the policy must be seen. Authority can come from attribution, namely the granting of new authority by a provision in a statutory regulation. In this case, a new government authority is born or created which originates from a delegation or mandate (Charda, 2012). Legislators who are competent to attribution of authority are distinguished between those who are original legislators and delegated legislators (Ridwan, 2011).

The government or the state administration is the subject of law, as a supporter of the rights and obligations - obligations (Charda, 2012). The government as a legal subject as well as other legal subjects takes various actions, both real actions (feitlijkhandelingan) and legal actions (rechtshandelingan) (Charda, 2012). Real actions are actions that have no relevance to the law and therefore do not cause legal consequences, while legal actions based on their nature can cause certain legal consequences or een rechtshandeling is gericht op het scheppen van rechten of plichten (legal actions are actions intended to create rights and obligations) (Soeprijanto, 2011).

The importance of the law as a limitation of authority so that there is no absolute abuse of authority which Lord Acton, a British historian, said as "power tends to be abused, but absolute power must be abused" (Charda, 2012). On the other hand, abuse of authority is often motivated by evil intentions, which if attached to power will be perfect or in other words crime will be perfect if it is attached to power, because with power officials can carry out actions under the pretext for and on behalf of the authority they have under the legislation. Such an official can be qualified as a human being who is not noble, because he earns income from crime (Charda, 2012).

\section{Legal Discretion and Certainty for State Administration Officials}

Discretion by a State Administration Officer is a State Administrative Legal Act, if an action/deed is carried out by a State Administration Officer in certain cases where the applicable laws and regulations do not/have not regulated it, or the existing regulations governing the said action/deed are unclear. / is disguised so that freedom of judgement is needed from the State Administration Official, and such actions/deeds can only be carried out in the sense of a state of coercion/urgency for the sake of the public interest that has been stipulated in a statutory regulation, with the following limits/benchmarks:

1) Discretion in the form of policy regulations must not deviate or conflict with the above rules. In the sense that it must comply with the hierarchy of laws and regulations;

2) The discretion used must not violate the human rights and obligations of citizens in the sense that it is not used arbitrarily;

3) The discretion used is still within the scope of the basic regulations;

4) The discretion is used in a state of coercion/urgency for the welfare/public interest;

5) The discretion used must be based on the AAUPL.

Meanwhile, Discretion by State Administration Officials constitutes Abuse of Authority which is categorized as a Corruption Crime, if an action/deed is carried out by a State Administration Official in certain cases where the applicable laws and regulations do not/have not regulated it, or existing regulations that regulate the action. / the act is not clear / disguised so that freedom of judgement is needed from the State Administration Official, but the action / action taken by the State Administration Officer deviates from what should be done, with the intention/intentional to benefit himself or others so that it can cause financial/economic losses countries which have been expressly regulated by law, with the following limits/benchmarks:

1) The discretion used deviates from the purpose of the regulations that underlie the authority of state administration officials and; 
2) The discretion used is intended to benefit oneself or another person or a corporation so that it can harm the state's finances/economics.

To ensure legal certainty and justice for the state administration in carrying out its duties to serve legal interests/realize public welfare, it can run dynamically, if there are legal instruments that regulate all processes of government administration so that they are able to protect citizens and the state administration itself. One of the legal breakthroughs that can be taken to realize a dynamic government administration is to form laws and regulations that materially regulate the government administration system including the decision-making process (Material State Administration Law).

The phenomenon of the criminal law system, especially in law enforcement against corruption, has an impact on decreasing the level of public trust in law enforcement officials, especially in providing legal certainty and fulfilling a sense of justice through efforts to overcome corruption which is very detrimental to the state. The low legal culture of this community can also be reflected in the formation of various corruption monitoring institutions, as well as other law enforcement institutions such as the KPK, BPKP and so on. This legal culture also has an impact on the weakness of law enforcement itself, so that this cycle becomes a system that influences each other which in the end law enforcement efforts are considered sterile by the community, contrary to legal ideals in the perspective of the criminal law system and the criminal justice system in Indonesia and hinder the purpose of law, namely the achievement of a sense of community justice.

Indonesia as a state of law, has been regulated in Article 1 paragraph (3) of the 1945 Constitution, previously regulated in the Elucidation of the 1945 Constitution, the role of judges in making court decisions, especially in the criminal justice system as described above, is very important, especially in providing a deterrent effect for perpetrators of corruption, as well as avoiding the emergence of controversial decisions, it is very strategic as the embodiment of independent judicial power and under the supervision of the Supreme Court in accordance with the provisions of Article 24 paragraph (1) and paragraph (2) of the 1945 Constitution. and the provisions of Article 2 of Law Number 4 of 2004. Court decisions in corruption cases must absolutely reflect a sense of justice for the Indonesian people in general and for justice seekers in particular.

\section{Conclusion}

Discretion by State Administration Officials is a State Administrative Law Act, if an action/deed carried out by a State Administration Officer The phenomenon of the criminal law system, especially in law enforcement against corruption, has an impact on decreasing the level of public trust in law enforcement officials, especially in providing legal certainty and the fulfilment of a sense of justice through efforts to overcome corruption which is very detrimental to the state. The low legal culture of this community can also be reflected in the formation of various corruption monitoring institutions, as well as other law enforcement institutions such as the KPK, BPKP and so on.

This legal culture also has an impact on the weakness of law enforcement itself, so that this cycle becomes a system that influences each other which in the end law enforcement efforts are considered sterile by the community, contrary to legal ideals in the perspective of the criminal 
law system and the criminal justice system in Indonesia and hindering the purpose of the law, namely the achievement of a sense of community justice.

\section{References}

[1] Atmosudirdjo, S. P. (1981). Hukum administrasi negara. Jakarta: Ghalia Indonesia.

[2] Jemi, J., Sudibyo, D., \& Wahyuengeseh, R. (2019, May). Challenges to accountability and transparency in implementing discretion in public services in Indonesia. In First International Conference on Progressive Civil Society (ICONPROCS 2019) (pp. 60-64). Atlantis Press.

[3] Koch Jr, C. H. (1985). Judicial review of administrative discretion. Geo. Wash. L. Rev., 54, 469.

[4] Kuntjoro, P. (1981). Beberapa Catatan Hukum Tata Pemerintahan dan Peradilan Administrasi Negara. Bandung: Alumni.

[5] Pratama, F. S. (2019). Rechtsvacuum Phenomenon in Government Regulation of the Republic of Indonesia Number 51 of 2020 related to Passport Renewal Period to 10 Years. Journal of Law and Border Protection, 1(1), 51-58

[6] Prins, W. F., \& Adisapoetra, R. K. (ed.) (1978). Pengantar Ilmu Hukum Administrasi Negara. Jakarta: Pradnya Paramita.

[7] Ridwan, H. R. (2011). Hukum Administrasi Negara. Jakarta: PT Raja Grafindo Persada.

[8] Setiadi, E. (2010, June). Kriminalisasi Kebijakan dan Bekerjanya Hukum Pidana. In Seminar Nasional Kriminalisasi Kebijakan, PDIH Unisba (Vol. 5).

[9] Sitorus, L. E. (2016). Kebijakan Bailout Century: Diskresi atau Kriminalisasi Kebijakan. Jurnal Hukum \& Pembangunan, 46(1), 22-49.

[10] Soeprijanto, T. (2011). Sumber-Sumber Kewenangan. Widyaiswara Pusdiklat PSDM.

[11] Syahnaz, A. Y. (2021). Korelasi Negara Kesejahteraan Dengan Demokratisasi Kehidupan Masyarakat sebagai Wujud Negara Paripurna. JURNAL SPEKTRUM HUKUM, 18(1).

[12] Ujang Charda, S. (2012). Potensi Penyalahgunaan Kewenangan Oleh Pejabat Administrasi Negara Dalam Pengambilan dan Pelaksanaan Kebijakan Publik. Jurnal Wawasan Hukum, 27(02), 588. 